\title{
LUCIANO E A EXPERIMENTAÇÃO BIOGRÁFICA: FILOSOFIA E RELIGIÃO
}

\author{
Pedro Ipiranga Júnior^ \\ Universidade Federal do Paraná
}

\begin{abstract}
The purpose of this work is based on the following issues: how the religious aspect is focused on biographical works and what constitutes its function; how religious discourse interferes with conception of the genre of biographical and literary prose from the perspective of Lucian of Samosata. For that we will use as a benchmark for our analysis some conceptions about the religious phenomenon in works with biographical tone of Isocrates, Plato and Xenophon, in order to check how Lucian resumes and refigure issues there proposed. In a kind of biographical account and in epistolary form, Lucian somehow promotes a mimesis (here in the sense of a critical refiguring) of reports of Bios, in which he enacts a moral action figure, syncretizes or juxtaposes philosophical adhesion and religious belief. In the biographical works of Lucian: The passing of Peregrinus, Alexander the false prophet, Demonax and somehow Nigrinus, 'conversion to a current philosophical' concerns a pathos in the discourse, which is staged so explicitly dramatized and therefore undergo a treatment critical. Thus, we treat this work in order to delineate the constitution of pathos of biographical discourse and status of a distinctive literary biographical prose linked to religious and philosophical questions.
\end{abstract}

KEYWORDS: Lucian of Samosata; biographical narratives; religious discourse; philosophical conversion; literary prose.

\section{Hyakíntoi Pétros hygiaínein}

uciano, em sua obra Sobre um tropeço na saudação, apresenta um narrador em primeira pessoa que, tendo cometido um deslize na hora

^junioripiranga@hotmail.com 
de saudar um amigo, resolve escrever uma pretensa apologia de sua falta, endereçada, pelo que se pode inferir, ao dito amigo.

De forma semelhante, embora tenha eu caído em falta mais grave, pareceu-me de bom-tom escrever a ti como uma forma de consolação a mim mesmo, a fim de que não me afligisse muito com a falta cometida e não me achasse intolerável se, em tal situação, resvalei num deslize contra a cortesia diante de tantas testemunhas. Difícil, sendo homem, escapar à maquinação de uma divindade, diria Luciano, mas muito mais difícil é achar uma defesa para uma falta absurda e ocasionada por um poder divino, ambas as quais a mim ocorreram, a mim que, tendo chegado junto a ti e estando sentado do teu lado, por ocasião do "II Simpósio de Estudos Clássicos da USP", em vez de me dirigir a ti ou ao público, enderecei o discurso a mim mesmo, lendo não o texto de uma palestra, mas o discurso de uma carta escrita por mim e a mim endereçada.

Em vista de tal procedimento e movido pelo arrependimento, resolvi neste simpósio escrever uma carta a ti e não mais a mim, como uma forma de retratação e como uma espécie de palinódia ante a falta anterior.

Três os aspectos a partir de que tenho analisado em trabalhos anteriores as narrativas de caráter biográfico de Luciano de Samósata: 1) o modo de endereçamento da obra, sendo aí relevante o emprego da forma epistolar; 2) a temática concernente à adesão ou não a uma crença, filosófica ou religiosa; 3) a estruturação das ações e caracteres dos personagens consoante um código teatral e um emprego de metáforas advindas do universo do drama e da encenação teatral.

Além desses três, acrescentaria um quarto aspecto a ser tratado: a constituição do gênero biográfico em relação a outros gêneros do discurso: o historiográfico, o encomiástico, o subgênero da oração fúnebre, o poético, os discursos narrativos do si mesmo, chamados por alguns comentadores simplesmente de autobiográficos, além, é claro, do discurso epistolar, reapropriado por Luciano em algumas das biografias.

Em vista disso, como estudo prévio, é necessário retomarmos as formas de classificação por parte de alguns estudiosos de tais narrativas. Num sentido mais geral e abrangente, Whitmarsh arrola quatro categorias de narrativas em Luciano: a primeira seria um tipo de relato fantasista, cujo único exemplar citado é a obra Das narrativas verdadeiras; a segunda categoria, mais relevante para a perspectiva aqui adotada, corresponderia a textos narrativos sobre religião, os quais se reduziriam a três: Sobre a deusa síria, Alexandre ou ofalso profeta e Sobre ofim de Peregrino. ${ }^{1}$

\footnotetext{
${ }^{1}$ Ele exclui dessa categoria Sobre os sacrifícios, Astrologia e Sobre os funerais, por entender não se tratar, nesses casos, de narrativas em sentido estrito.
} 
A terceira categoria abarcaria as prolaliaí (discursos introdutórios que precediam performances mais longas), entre os quais estariam Dioniso, Héracles, Dípsadas, Heródoto, Zêuxis. À quarta categoria pertenceriam os diálogos, classificados em dois tipos: os miméticos e os narrativos. No primeiro, uma situação dramática é encenada, a exemplo do que acontece em Dupla acusação, em que o personagem apelidado de "o Sírio" é julgado diante de um tribunal. No segundo tipo, a instância do narrador, ocupada por uma figura do alter ego de Luciano, apresenta e conduz a narrativa, com interferência também da figura do narratário, cujo exemplo evidente seria o diálogo Nigrino.

Para Whitmarsh, há nos diálogos um nível de narrador primário, um narrador, segundo ele, mais diretamente associado à figura do autor, o qual estaria subjacente e anterior ao nível dos interlocutores do diálogo dito mimético. Estes interlocutores seriam, por seu turno, narradores secundários, cujo nome evocaria a identidade do narrador primário. Nessa ótica, os personagens Licino, o Sírio, Momo, Parresíades, Cinisco, Menipo, Tiquíades seriam figuras narradoras de um alter ego, cumprindo o papel de enunciar a voz, em menor ou maior medida desfocada, do narrador primário. ${ }^{2}$

Num estudo sobre a função e a enunciação do "eu" na obra luciânica, Suzanne Saïd, embora esclareça que não haveria aí propriamente autobiografia, perfaz uma delimitação do que apareceria como autobiográfico. Ainda que não esteja preocupada com uma taxinomia rigorosa, ela divisa dois tipos de relato autobiográfico: por um lado, os diálogos em que Luciano se coloca em cena sob pseudônimos (chamados por Whitmarsh de diálogos de alter ego); por outro lado, as cartas ou os relatos em que o "eu" do autor se confundiria com o "eu" do narrador, o qual às vezes é o próprio herói da história. ${ }^{3}$

É importante divisar que essa classificação de teor autobiográfico se sobrepõe, principalmente tendo em mente o segundo tipo, a uma delimitação de textos propriamente biográficos, o que devém do fato de que a biografia em Luciano, por lançar mão de narrador intradiegético, é o tipo de obra que apresenta aspecto marcadamente autobiográfico, em que são relatados eventos pretensamente retirados da vida do autor. Segundo Suzanne Saïd, além de uma função retórica que mimetiza o valor da "autópsia" do discurso historiográfico, os detalhes

\footnotetext{
${ }^{2}$ Cf. Whitmarsh, op. cit., p. 468-469.

${ }^{3}$ Cf. Saïd, op. cit., p. 253-254.
} 
autobiográficos, em vez de proporcionarem um conhecimento da personalidade do autor, visariam a "garantir a veracidade do que se vai dizer pelo fato de que ele assistiu, ou melhor, esteve envolvido de perto nos eventos que ele conta", ou seja, o autobiográfico não passaria de um meio para validar a biografia, fornecer ao destinatário um amparo testemunhal para gerar ou simular confiança no que é relatado.

De uma perspectiva diferenciada, para Jacyntho Lins Brandão, estes textos em que aparecem pseudônimos de Luciano, de uma forma ou de outra, não recebem a chancela de Luciano num sentido forte, em comparação a uma categoria de textos em que aparece a assinatura do escritor, ou seja, textos em que o nome "Luciano" figura concretamente como narrador. Tais textos assinados seriam os seguintes: Sobre o fim de Peregrino, Alexandre ou o falso profeta, Carta a Nigrino, Das narrativas verdadeiras e Epigrama 1. Com relação aos três primeiros, o helenista ressalta o fato de possuírem em comum uma forma introdutória epistolar, apresentando um cabeçalho em que são marcados e individualizados o remetente, que assina sob o nome de Luciano, e o destinatário, Crônio, Celso e Nigrino, respectivamente, três figuras de filósofos assimilados a personagens históricos da época.

Como Suzanne Saïd, ele acredita que esse enquadramento autobiográfico, no caso estritamente delimitado pela assinatura, visaria a garantir a veracidade do que é dito, porém, além disso, estaria a serviço da denúncia, função essa que caracterizaria a biografia luciânica. Ademais, a forma epistolar, além de sublinhar as marcas da escrita evidenciando o valor documental e, de certo modo, doutrinal do escrito, criaria um tipo de intimidade entre autor e destinatários e atenderia a uma função também panfletária de desmascaramento, haja vista que em Alexandre e Peregrino o narrador-Luciano investe contra figurados biografados, no esforço de revelá-los como charlatães. ${ }^{5}$

Outra forma de classificação, aduzida por Diskin Clay, se afigura igualmente importante para a nossa análise. Segundo ele, haveria, de um modo mais genérico, uma qualidade de escritos luciânicos devotados a simular uma fraude ou a desmascarar uma fraude, entre os quais estariam Sobre a deusa síria, Alexandre ou o falso profeta e Sobre o fim de Peregrino. Outra forma de classificação seria agrupar textos em que Luciano evidenciaria seu interesse pela filosofia, segundo duas formas

\footnotetext{
${ }^{4}$ Cf. Saïd, op. cit., p. 257.

${ }^{5}$ Cf. Brandão, op. cit., 1992, p. 490-497.
} 
diferentes de enfocar os filósofos: em primeiro lugar, estariam os diálogos em que os filósofos são retirados do passado e apresentados em cena, por exemplo, em $O$ sonho ou o galo, Leilão de filósofos, O pescador, entre outros. Em segundo lugar, estariam os textos concernentes a seus contemporâneos, filósofos ou taumaturgos que teriam seu campo de ação num mundo de cultura helenizada e de dominação romana. Embora cite o Hermótimo e o Eunuco dentro de classe, o estudioso restringe a quatro obras o corpus de textos que ele define como "vidas filosóficas", a saber: o Nigrino, o Demônax, o Peregrino e o Alexandre, ou seja, bíoi em que Luciano manifestaria seu interesse pela filosofia.

Segundo Clay, não haveria nestas vidas um debate de ideias filosóficas, mas a filosofia aí se restringiria a um modo de vida, ou seja, à exposição narrativa da vida do biografado revelando seus princípios morais e as ações correspondentes. ${ }^{6}$ Além disso, essa figuração da filosofia se expressaria sob a forma de uma performance teatral, por meio dos protagonistas dos bíoi. Esse último aspecto estaria estreitamente vinculado ao movimento da época conhecido como Segunda Sofística, a partir do fato de que os sofistas deste segundo século viajavam pelas grandes cidades apresentando-se segundo uma performance propriamente teatral, tal qual se explicita nos vários relatos de Filóstrato em Vidas dos Sofistas.

Neste sentido, a crítica de Luciano visaria, a princípio, a essa teatralização da filosofia, a performance da filosofia como espetáculo e como mera aparência. Não obstante, das quatro obras apenas duas se enquadrariam numa forma de censura e de denúncia (Alexandre e Peregrino), enquanto as outras duas (Nigrino e Demônax) se situariam no campo da biografia encomiástica. Todavia, para Diskin Clay, as personae de Nigrino e Demônax não seriam figuras históricas, mas antes constituiriam modelos paradigmáticos, construídos por Luciano, a fim de servirem como referência e critério de alteridade em relação e contraposição aos filósofos contemporâneos que pretendia atacar. Em Demônax, por exemplo, aparecem, entre outros, Favorino de Arles, Honorato, Peregrino de Párion, Herodes Ático, o peripatético Agátocles, cuja função, sob a ótica desse estudioso, seria a de confirmar a realidade histórica de Demônax. Para ele, tratar-se-ia de uma ficção histórica devedora de uma tradição que remonta à Ciropedia de Xenofonte, tendo por finalidade conceber uma figura de filósofo como paradigma para sua própria época. ${ }^{7}$

\footnotetext{
${ }^{6}$ Cf. Clay, op. cit., p. 3412-3413.

${ }^{7}$ Cf. Clay, op. cit., p. 3427.
} 
Se tentarmos articular esses diversos critérios de classificação, chegamos, inicialmente, a uma primeira classe que apresentam dois critérios: a assinatura de Luciano como chancela do autor e a tematização sobre a adesão, ou melhor, o processo de adesão a uma crença filosófica e/ ou religiosa (ou, segundo os termos de Clay, sobre a simulação ou desmascaramento de uma fraude). Nesta categoria ficariam $O$ fim de Peregrino e Alexandre ou o falso profeta. A posição do Nigrino é, de certo modo, ambígua e incerta neste grupo. Stricto sensu, trata-se de um diálogo não assinado, uma vez que a assinatura de Luciano apareceria apenas na Carta a Nigrino que prefacia o diálogo propriamente dito; ${ }^{8}$ ademais aí não se expõe um percurso biográfico, porém apenas um momento, crucial certamente, na vida do interlocutor-narrador concernente à sua conversão à filosofia motivada pelo lógos do filósofo Nigrino.

De uma forma ou de outra, se levarmos em conta a concepção mais abrangente de narrativa de Whitmarsh, o Nigrino e o Demônax formariam uma classe de narrativas biográficas não assinadas, em que está presente igualmente a tematização do processo de filiação a uma corrente de pensamento. Tal tematização, contudo, não nos parece radicarse num interesse voltado preferencialmente para a filosofia, como a argumentação e a classificação de Diskin Clay parecem indicar, mas para uma área em que estão imbricados os campos da filosofia e da religião.

É o historiador Momigliano quem afirma que então a exploração biográfica passou "a ser um modo essencial de descrever e compreender a religião". 'Situa ele em Luciano o momento prévio da polêmica direta com o cristianismo, a exemplo do tratamento que a figura de Cristo recebe em Sobre o fim de Peregrino; mostra, ademais, como grandes contribuições à história da religião o seu estudo do contemporâneo Alexandre de Abonotico na obra homônima e sua descrição do culto da deusa síria em Hierápolis. Segundo o italiano, mais importante do que o relato sobre as figuras biografadas, a biografia pode expressar as atitudes religiosas ou irreligiosas do biógrafo. Tal se afigura, nos escritos luciânicos, de grande relevância, em função da relação que ele procura estabelecer entre os vários níveis de narrador e seus destinatários correlatos, cujas personalidades e caracteres são constituídos discursivamente nas próprias obras.

${ }^{8}$ Cf. Clay, op. cit., p. 3421, n. 27. Aí ele cita outros exemplos de cartas que introduzem um diálogo, como, por exemplo, o Protréptico de Aristóteles.

${ }^{9}$ Cf. Momigliano, op. cit., 1992, p. 37. 
Por conseguinte, é mister em nosso estudo considerar, por um lado, a produção luciânica classificada por Whitmarsh como diálogos de alter ego, a fim de verificarmos de que modo essa atitude irreligiosa é configurada e, por outro lado, como a simulação de crença é suscitada num relato como Sobre a deusa síria, composto num estilo arcaizante que mimetiza a escrita historiográfica de Heródoto.

No século II d.C., os gêneros do romance e da biografia vão tematizar a cultura religiosa de sua época. A questão da providência divina e aquela correlata da fortuna fazem parte da agenda filosófica e religiosa. No romance, uma das expressões mais corriqueiras na narrativa é "de repente"; a ação da fortuna irrompe no relato como que conduzindo o enredo montado a partir de vários "de repente", "subitamente", "por acaso". É em relação a esse polo da fortuna que, por exemplo, na obra $O$ asno de ouro, de Apuleio, a epifania de Ísis vai intervir; aparecendo ao personagem Lúcio, ela o situa em uma outra esfera, ela assegura para ele a salvaguarda de sua proteção e de sua providência. Qualquer que seja a interpretação que façamos das Metamorfoses, é inegável que o autor está jogando com esses dois polos da fortuna e da providência na condução da narrativa e do destino do herói.

É essa noção de providência divina e é esse tipo de religiosidade ávida de oráculos, milagre e curas que Luciano vai criticar em várias de suas obras. Em textos como Zeus trágico e Zeus refutado, ele elabora uma argumentação de base epicurista para refutar as teses do personagem de Zeus que defende a vantagem e os benefícios de se honrarem os deuses. Segundo Caster:

Estas duas noções [a Providência e deus], que eram praticamente inseparáveis em sua época, o são igualmente nele [em Luciano]. Em Zeus trágico e Zeus refutado, esta identidade é visível a cada instante. (...) Tudo o que atinge a Providência atinge os deuses. Assim, quando Cinisco (Zeus Refut. 15) opõe à Providência a lei do Destino, os deuses são ameaçados: se a providência é destruída pelo Destino, os deuses são deuses "para nada". 10

Assim, em Zeus refutado, a partir da argumentação acerca da ação irreversível e imutável das Moiras, o personagem de Cinisco demonstra a inutilidade tanto das ações humanas em sua piedade para com os ritos e com os deuses, quanto das próprias ações dos deuses, também postos em relação de submissão à heimarméne, ao domínio das Moiras. Em

${ }^{10}$ Cf. Caster, op. cit., 1937, p. 144-146 (trad. nossa). 
consequência, o sistema ético também é abalado, pois, se tudo é devido a uma necessidade inevitável, a conduta e a ação do homem não seriam espontâneas, ninguém podendo ser responsável ou pelo bem ou pelo mal.

$\mathrm{Na}$ obra Zeus trágico, há um agón entre dois personagens representando estas duas atitudes face aos deuses e à providência: de um lado, o filósofo estoico Tímocles, defendendo o caráter providencial da divindade; de outro, o filósofo epicúrio Dâmis, atacando a noção de providência, a utilidade e a existência dos deuses; há um público que assiste ao embate, no plano humano, e outro, no plano divino, estando os deuses, principalmente Zeus, temerosos pelo desenlace da disputa. Aqui a argumentação é mais diversificada; além da refutação via argumento baseado na noção de destino, apela-se para a variedade de crenças, de oráculos, de variantes de histórias e mitos sobre os deuses que seriam contraditórios entre si. Outro argumento diz respeito à natureza do mal, ou melhor, à ocorrência do mal, que contradiz a existência de uma justiça divina segundo o raciocínio seguinte: enquanto os bons, muitas vezes, não recebem recompensa por seus atos, os homens vis conquistam riquezas.

Se, por um lado, Luciano, em consonância com a ambiência de seu tempo, considera como sinônimos a concepção da divindade e a concepção da Providência, por outro, ele põe em relação estreita com esta última "os oráculos, os sacrifícios ou votos, a fé na imortalidade e talvez o maravilhoso". ${ }^{11}$ No que diz respeito a um dos pontos que desejamos enfocar, a passagem referente à interpretação feita pelo personagem de Momo do oráculo de Apolo é esclarecedora: asno seria aquele que especula sobre tais questões divinas e mulas aqueles que acreditam em seus discursos. Dessa forma, no Asno de Luciano, o narrador-protagonista se transforma em asno em decorrência de sua afecção por magia, assim como os leitores se transformam em mulas ao acreditarem nele. A transformação em asno é representada pelo assentimento, pela adesão a uma crença, o que, de certo modo, é retomado no Hermótimo.

Em contraposição a essa configuração narrativa da obra luciânica, na obra homônima de Apuleio, o sentido é revertido; o estado de asno seria prefigurado por todo aquele que se atrela a uma forma de religiosidade, de maneira despreparada e sem os princípios morais pressupostos para tal. Esta forma de religiosidade está vinculada a uma

${ }^{11}$ Cf. Caster, op. cit., 1937, p. 147. 
sexualidade desenfreada e ao mundo dos lances imprevisíveis da fortuna e da Týkhe. Escapar da roda da fortuna é livrar-se da pele do asno e dos sofrimentos e desventuras a ela atrelados. No entanto, enquanto para um, em Apuleio, há uma forma de religiosidade superior capaz de alcançar a redenção do homem, para o outro, a atitude, por excelência, do homem que quer se voltar a um credo religioso ou filosófico é descrer, não acreditar, adotar sempre uma atitude crítica em relação aos princípios dos outros e de si mesmo.

No entanto, em determinado texto luciânico, Sobre a deusa síria, o narrador luciânico adota um outro ponto de vista em relação à religião e em relação aos santuários. Nessa obra, numa mímesis explícita de Heródoto, inclusive no dialeto jônico, ele se propõe falar sobre Hierápolis, a cidade dedicada à deusa Hera, tratando do seu templo, dos relatos de sua fundação, das festas, ritos, sacrifícios e costumes. Inicialmente, ele descreve vários outros templos e santuários da região da Síria em sua época; em seguida, concentra-se num pretenso relato historiográfico de Hierápolis.

Embora aduza poucos exemplos, o narrador de Sobre a deusa síria não deixa de relatar alguns prodígios realizados por intermédio das esculturas de madeira do templo representando os deuses: elas suam, movem-se, profetizam e, mesmo, chegam a gritar. ${ }^{12}$ Os prodígios aqui, ao contrário do que ocorre nos outros escritos de Luciano, não são reputados como falsos ou como truques para enganar o público e promover uma crença desprovida de juízo crítico; em função desse tratamento do tema, esta obra é muitas vezes considerada como espúria, porque fugiria do modo de Luciano se posicionar sobre o assunto. De qualquer modo, um clima irônico e, por vezes, satírico retiraria do texto qualquer traço de adesão séria ao que é narrado. ${ }^{13} \mathrm{O}$ interessante aí é que são evocados, por um lado, os milagres, de forma bem parcimoniosa, e por outro, o páthos erotikón, com uma descrição que faz referência explícita ao discurso da medicina de então.

Conta o narrador luciânico algumas histórias concernentes a Estratonice, esposa de Seleuco Nicátor, a qual seria responsável pela reconstrução do templo da cidade sagrada de Hierápolis. O filho do rei, seu enteado, teria se apaixonado por ela e, premido pela vergonha, ocultava sua paixão, ao mesmo tempo em que adoecia a olhos vistos. A cor de sua pele se alterou completamente e seu corpo se debilitava a

${ }^{12}$ Luciano, Sobre a deusa síria, 10.

${ }^{13}$ Cf. Whitmarsh, op. cit., p. 467. 
cada dia. Esse estado patológico foi notado rapidamente pelo médico, o qual, depois que verificou que não havia nenhuma enfermidade notória, chegou ao diagnóstico de que se tratava do mal do amor, com os seguintes sintomas: olhar desvanecido, alteração da voz e da cor da pele, lágrimas sem razão. Como se tratava de um amor secreto, concebeu o médico um estratagema para descobri-lo: apalpando o peito do jovem na altura do coração, mandou chamar, um a um, todos os da casa; enquanto permaneceu tranquilo na presença de todos os demais, com a chegada de Estratonice, ele começou a suar, sua pele mudou de cor e seu coração se pôs aos pulos. $\mathrm{O}$ acontecido evidenciou ao médico a paixão amorosa e a causadora de tal estado.

Diagnosticada a afecção amorosa, o médico também providenciou a cura. Fingindo tratar-se de sua própria esposa a pessoa amada pelo jovem, levou o rei a admitir que, para salvar a vida do filho, consentiria até mesmo em ceder-lhe a esposa. $\mathrm{O}$ médico esclarece a situação e o rei deixa que o filho despose Estratonice. Esta, então, a cura do mal do amor, do páthos erotikón: o casamento. De uma forma ou de outra, a narrativa de eventos eróticos dentro de uma obra pretensamente historiográfica parece evocar as cenas romanescas da Ciropedia de Xenofonte.

Cabe, então, focar a análise novamente para o discurso biográfico que se descortina nessas várias formas narrativas experimentadas por Luciano. Sem dúvida, a arrolagem de anedotas é um dos traços mais característicos de um tipo de biografia que Luciano emprega mais extensivamente no Demônax, o que remontaria aos Memorabilia de Xenofonte.

Enquanto Peregrino é cognominado de Proteu, em vista da artificialidade do seu engajamento, pela mudança de uma doutrina a outra (exemplificada por sua adesão ao cristianismo, seguida de sua saída para adotar o cinismo), Demônax, embora tenha tido mestres de várias facções e correntes, adota uma posição de autonomia em relação às doutrinas, mas segundo uma conduta coerente e moralmente insuspeita.

$\mathrm{O}$ traço marcante que assemelha a figura de Demônax àquela de Nigrino (e que distingue as personagens, como Menipo, nos Diálogos dos mortos, encarregadas de enunciar a perspectiva, por assim dizer, valorizada por Luciano) é o rir, o zombar, o escarnecer, expresso pelo verbo geláo e seus compostos. Com efeito, é em função dessa ação desconstrutora do riso que Peregrino intervém como personagem também no Demônax, censurando o outro por não se comportar como cínico ao zombar sempre dos homens, ao que ele retruca que aquele 
não age nem se comporta como homem. ${ }^{14} \mathrm{O}$ riso tem uma função de distanciamento, de contestação das convenções, das opiniões preconcebidas, das manifestações de vanglória, da hierarquia social, do arraigamento das posições sectárias, do poder ligado aos cargos e magistraturas romanas, da ostentação de riquezas. Ele causa, de todo modo, uma espécie de corte, de suspensão da crença, de retirada da adesão dos sujeitos do discurso.

Ao contrário do Nigrino e de Sobre o fim de Peregrino, não há no Demônax, do ponto de vista do narrador, uma explicitação do caráter dramático da composição, mas é possível considerar a passagem em que se expõe a efemeridade das alegrias e tristezas humanas, em sua dependência da sorte, ${ }^{15}$ uma evocação do teatro do mundo indicado no Nigrino. Ademais, concordamos com Branham ${ }^{16}$ em que as várias anedotas narradas acerca de Demônax se afiguram como vários momentos dramáticos, espécies de flashs que poderíamos aproximar, nesse sentido, da estruturação em microdiálogos dos Diálogos dos mortos. Essas anedotas, sob a forma de crias, são a principal marca formal da obra, abrangendo a maior parte do texto. ${ }^{17}$ A estruturação em crias ou apotegmas está associada à literatura cínica, suas origens, como foi dito, remontam a Xenofonte, com sua coleção de ditos memoráveis de Sócrates. ${ }^{18}$ Isso atesta que a experimentação luciânica no terreno do bíos ocorre de forma consciente e quase sistemática, de tal modo que ele faz uma apropriação do gênero de acordo com a espécie do relato biográfico que quer evidenciar e colocar em primeiro plano.

A influência dos exercícios retóricos, os progymnásmata (crias, prosopopeias, bem como, de certo modo, a carta), é bem atestada na obra de Luciano, mas seriam estes, segundo Bompaire, pouco ou mal

\footnotetext{
${ }^{14}$ Luciano, Demônax, 21. Há um jogo de palavras: a expressão usada tanto significa "não agir como cínico" como "não agir como cão", a que se contrapõe o "não agir como homem".

${ }^{15}$ Luciano, Demônax, 8.

${ }^{16}$ Cf. Branham, op. cit., p. 61.

${ }^{17}$ Esta estruturação de um relato biográfico baseado em crias (khréiai) é curiosamente o que caracteriza a segunda parte da Vita Antonii; no entanto, aí os pequenos trechos são um pouco mais desenvolvidos que uma cria tradicional, o que se tornaria o tipo padrão de composição para as coleções de apotegmas dos padres do deserto, sucessores de Antônio.

${ }^{18}$ Diógenes Laércio VI, 20-81; Xenofonte, Memorabilia; Jones, op. cit., p. 91; Branham, op. cit., p. 58; Berger, op. cit., p. 80-88.
} 
praticados por ele. ${ }^{19}$ Não obstante, este não parece ser o caso do Demônax, em que se verifica a forma mais completa do emprego de crias na literatura do segundo século. ${ }^{20}$ Em relação às cartas, como temos argumentado, explicita-se, mormente nos relatos biográficos aqui analisados, sua função na dinâmica da teatralidade e na problematização da dýnamis do discurso.

Alguns comentadores são seduzidos pela forma amável e elogiosa segundo a qual se constrói a imagem de Demônax no texto luciânico. O seu perfil biográfico, quanto ao tratamento dos tópoi do bíos no relato cronológico das ações, é comparável apenas àquele do "falso profeta" no Alexandre. Jones aceita, com reservas, alguns dados biográficos do Demônax, mas considera haver aí um sincero envolvimento pessoal da parte de Luciano, o que tornaria a obra uma "espécie de autobiografia indireta". ${ }^{21}$ Entretanto, não vejo por que não considerá-lo da mesma perspectiva dramatizada do Nigrino, tanto mais porque aí não há a chancela fornecida pela assinatura de Luciano. Dessa forma, Demônax não se enquadraria na espécie de relato biográfico que temos definido e especificado na obra luciânica, pois não seria "assinado", nem apresentaria uma forma epistolar. De qualquer modo, sua análise é funcional para nos revelar uma série de contrapontos e analogias que apresenta em relação àqueles que têm a assinatura de Luciano (Nigrino, Sobre o fim de Peregrino, Alexandre ou o falso profeta), o que denotaria uma certa sistematicidade no uso do gênero.

Em trabalho apresentado no "IV Colóquio do GIPSA", intitulado Retórica e dramaticidade em Luciano de Samósata, propúnhamo-nos examinar a função da representação do teatro em algumas narrativas luciânicas. Chegamos à conclusão, por um lado, de que isso diz respeito a uma relação intrínseca com o princípio de comunicabilidade retórica da obra; dito de outra forma, para analisar a configuração de uma obra em sua relação com determinado tipo de público, quer em vista dos efeitos visados sobre ele, quer em função de suas expectativas, lança ele mão de uma analogia com o teatro, que é o gênero em que a concretização da obra se realiza diante e em presença da assistência. Por outro lado, a remissão à figura do ator diz respeito às fronteiras entre o que é ilusão, no sentido de enganar propositadamente ou de ser enganado ingenuamente, e o que é uma representação que marca indiscutivelmente a sua qualidade de ficção.

\footnotetext{
${ }^{19}$ Cf. Bompaire, op. cit., p. 303.

${ }^{20}$ Cf. Jones, op. cit., p. 93.

${ }^{21}$ Cf. Jones, op. cit., p. 98.
} 
Além da referência ao teatro, a outra forma de que Luciano se utiliza nas narrativas biográficas, como já falamos inicialmente, para representar tanto o lugar do escritor quanto o lugar do narrador e do leitor, é o enquadramento epistolar. Desse modo, o destinatário da carta é alguém especializado no assunto tratado, quer seja a história, quer sejam correntes de pensamento ou sistemas de crença. Em Como se deve escrever a história, por exemplo, Luciano situa a perspectiva do crítico em relação à narrativa histórica em função de seu alinhamento com o cinismo, citando uma anedota sobre Diógenes, pois é a forma luciânica de valorizar a alteridade e o papel da denúncia social, característicos dos filósofos cínicos. Por outro lado, em Sobre o fim de Peregrino, tanto o cinismo quanto o cristianismo nascente são criticados por Luciano.

Eis o seu começo, também em forma epistolar: Loukianòs Kroníoi ê̂ práttein ("Luciano a Crônio, saudações"). ${ }^{22}$ Embora contenha um relato pretensamente biográfico, relativamente longo, no interior da narração o que é frisado pelo narrador, desde o princípio, e que vem a ser o clímax da narrativa (conquanto simulando o narrador certo desinteresse) concerne diretamente ao fim que Peregrino sofreu (épathen), com a última transformação por que passou, sendo comparado, assim, à figura mitológica de Proteu, personagem da Odisseia; aqui o narrador é acometido pelo riso, assim como o rir é a reação que espera de seu destinatário ao ouvir os eventos narrados.

Peregrino é chamado de poeta (poietén) cuja composição seria a própria vida, da qual, como Sófocles ou Ésquilo, fazia a representação de forma trágica (etragóidei), ${ }^{23}$ ou seja, investe-se na teatralização do protagonista para caracterizá-lo negativamente. O narrador faz também aqui o papel de ator que, como o mensageiro trágico, narra pela recordação dos discursos (apomnemoneûsai) a sequência dos acontecimentos no drama. A epídeixis em Sobre o fim de Peregrino é bem mais explícita na sua remissão às artes plásticas, pois o ato de contemplar o bíos desse Proteu é comparado à visão da estátua de Zeus olímpico, afigurando-se a sua morte (segundo o ponto de vista do seu discípulo Teágenes, procedente do cinismo) como o desaparecimento de uma obra de arte de inestimável valor.

A tragédia aqui é enfocada no sentido de um teatro de ilusão, cuja cena principal é montada durante a realização dos Jogos Olímpicos e cujo objetivo, segundo Luciano, seria a busca desenfreada de glória. O tom de

\footnotetext{
${ }^{22}$ Luciano, Sobre ofim de Peregrino, 1.

${ }^{23}$ Luciano, Sobre ofim de Peregrino, 3.
} 
tragédia é conferido pela perspectiva de uma morte anunciada, a qual, como cena final, é preparada para ser vista e julgada como um grande espetáculo público. ${ }^{24}$ Antes do desenlace do drama (tèn katastrophèn tôิ drámatos), o personagem de Luciano, semelhantemente ao que acontece no Alexandre, entra em confronto com o próprio Peregrino: aqui é por uma explosão de riso após o discurso de Peregrino que o narrador faz a sua afronta, colocando a si mesmo numa situação de perigo. ${ }^{25}$

O destinatário, pela remissão feita ao riso de Demócrito, se tinge de tons epicuristas. O narrador, à guisa de chacota, simula, depois da morte do cínico, na mesma linha dramática vivenciada pelo cognominado Proteu (etragóidoun), uma narrativa fabulosa de fenômenos admiráveis que haviam sucedido. ${ }^{26}$ De qualquer modo, o intuito continuava o mesmo: contrapor ao juízo daqueles caracterizados pela falta de discernimento (e por uma crença míope) o julgamento crítico e abalizado de quem tem a capacidade de avaliar a situação e as questões nela envolvidas de forma reflexiva e ponderada; daí, pode-se inferir que a consciência de desempenhar um ou mais papéis no drama não deixa de se amparar numa cenografia discursiva que encena o julgamento de si mesmo, vinculado ao contexto social, político e, sobretudo, cultural (aí estando incluída, de certo modo, a esfera religiosa) com que interage.

No Peregrino, de fato, há a narração dos eventos básicos da vida do protagonista, redigida segundo a maneira dos biógrafos de então, mas ela é feita por um personagem narrador e não narrador em primeira pessoa. ${ }^{27}$ Esse narrador, que assina o escrito sob o nome de Luciano, narra os eventos por ele presenciados durante os Jogos (provavelmente de 165), encarregando-se da narrativa da morte de Peregrino, que é o grande evento anunciado desde o início e que dá nome ao relato.

Peregrino (descrito em seu figurino segundo a aparência exterior de um cínico: bastão, manto gasto, alforje) é considerado, pelas pessoas de sua cidade, um autêntico herdeiro de Diógenes e do cinismo. O que se despreza neste é justamente a capacidade de iludir, de dissimular a realidade e de suscitar a crença, contraposta pelo narrador a uma forma

\footnotetext{
${ }^{24}$ Luciano, Sobre ofim de Peregrino, 15, 21-22, 35-36. Luciano tem em vista, certamente, o abismo que separa a realidade do ator que porta a máscara do personagem representado.

${ }^{25}$ Luciano, Sobre o fim de Peregrino, 37.

${ }^{26}$ Luciano, Sobre ofim de Peregrino, 39.

${ }^{27}$ Cf. Schwartz, op. cit, p. 90-91.
} 
de desmascarar e censurar os falsos filósofos, os falsos valores e a adesão irrefletida a crenças e doutrinas. $\mathrm{Na}$ verdade, o critério básico para se avaliar o quilate de um filósofo é de ordem moral: a coerência entre os princípios advogados por ele e o seu modo de vida, em que pode ser verificada a aplicação prática daqueles. É bem o que se depreende do modo de ser de Nigrino na narrativa luciânica de mesmo nome, pois este vivia de modo simples, ensinava sem cobrar e ajudava os necessitados, desprezava os bens materiais, as honras e os prazeres, mantinha uma dieta frugal e uma prática moderada de exercícios, sendo ponderado e de caráter doce e amável. ${ }^{28}$ Já com relação a Peregrino, a acusação de ter matado o pai, mencionada em vários momentos, invalida qualquer possibilidade de admiração por sua conduta moral, o que marca de hipocrisia, dissimulação e arrivismo qualquer tentativa sua nesse sentido. Longe de querer vivenciar genuinamente os princípios filosóficos ou religiosos, sua intenção seria, segundo a letra do texto luciânico, exibir um determinado tipo de atitude com o intuito de provocar a admiração e de forjar uma ilusão para o público.

Assim, divisamos esta finalidade da narrativa biográfica em Luciano: proporcionar uma cenografia discursiva tal que as ações, nesses casos de um filósofo, registradas no espaço de tempo referente ao seu bíos, possam ser contempladas pelo público e, por conseguinte, avaliadas e julgadas. O relato biográfico lhe é, portanto, funcional, porque permite uma contextualização das ações do biografado no espaço do que é indicado como realidade efetiva, segundo a perspectiva do gênero bíos, levando o sujeito dramático a fazer a sua ação no discurso, a saber, colocar o outro (e a si mesmo) em julgamento. A teatralidade na obra luciânica, além da gama de sentidos mencionados, receberia sua dinâmica, em certo grau, através da dramatização de uma situação que envolve todos os elementos e sujeitos do discurso num julgamento de valor. Esse drama seria orquestrado por aquela figura que temos definido pelo narrador em primeira pessoa e seria representado por aquela outra, um certo leitor, um certo ouvinte, um certo espectador, cujo juízo deve ser experimentado na esfera, discursivamente constituída, do si mesmo.

O grande espetáculo final de Sobre o fim de Peregrino diz bem dessa dramatização, feita em dois níveis. Por um lado, o narrador, presente ao evento, conta que uma multidão acompanhava Peregrino, uns condenando, outros louvando o seu projeto, a sua escolha (tèn proaíresin). ${ }^{29}$

\footnotetext{
${ }^{28}$ Luciano, Nigrino, 26.

${ }^{29}$ Luciano, Sobre o fim de Peregrino, 32.
} 
As pessoas presentes, após a oração fúnebre que Peregrino enunciou acerca de si próprio, emitiam suas opiniões. Por outro lado, a narração é entrecortada pelas várias remissões feitas ao destinatário, Crônio; o ego-narrador sempre o imagina rindo, compartilhando o mesmo ponto de vista: julgar Peregrino como alguém completamente sedento de glória (dóxes), desejando, a todo custo, ser admirado e venerado. ${ }^{30}$

Embora Peregrino seja retratado como cínico (e, em certo momento, como cristão), o que se critica não é o cinismo, mas a representação do modo de ser cínico como puro espetáculo, como um teatro de ilusão. Sem embargo, as principais características do verdadeiro filósofo, nos textos luciânicos, são retiradas, segundo Brandão, ${ }^{31}$ do modelo cínico, já que o cinismo em si mesmo seria menos caracterizado por uma doutrina do que por uma atitude pragmática diante da vida, daí decorrendo uma prevalência da prática sobre qualquer aspecto doutrinário. Além disso, os cínicos, por seu caráter marginal na sociedade, se prestariam melhor ao papel de crítica e de denúncia social. ${ }^{32}$ Conquanto no Peregrino a liberdade no falar e no agir degringole num modo fanático de ataque pessoal e em ações desarrazoadas, os ideais de eleuthería, parresía e autárkeia vêm a ser os constituintes positivos delineados nas figuras que, como Nigrino e Demônax, se tingem com tons do modelo cínico.

A encenação do páthos da escolha religiosa está vinculada a um discurso de caráter testemunhal e que versa, de uma forma ou de outra, sobre prodígios. É característica dessa época uma literatura de prodígios, que poderíamos adjetivar de aretológica, ainda que não constitua um gênero determinado. ${ }^{33} \mathrm{O}$ que se tem argumentado é que, nesse relato biográfico, assinado e em forma epistolar, a intenção de Luciano é, de certo modo, promover uma mímesis (no sentido aqui de uma refiguração crítica) de relatos de bíoi, na qual se encena a ação moral de uma figura que, a exemplo de Peregrino, sincretiza ou justapõe adesão filosófica e crença religiosa. Estáem questão, portanto, o páthos que um tal discurso suscita naqueles que se veem obrigados a fazer uma escolha filosófica e/ ou religiosa. O relato biográfico visa, assim, a colocar em cena a vida de um líder religioso ou de

\footnotetext{
${ }^{30}$ Luciano, Sobre o fim de Peregrino, 134.

${ }^{31}$ Cf. Brandão, op. cit., 1992, p. 183-188; Caster, op. cit., 1937, p. 68; Adrados, op. cit., p. 688.

${ }^{32}$ Cf. Ipiranga Júnior, op. cit., 2000, p. 45-47; Paguet, op. cit., p. 9; Diógenes Laércio VI, c.1, 11.

${ }^{33}$ Cf. van Uytfanghe, op. cit., p. 141-143.
} 
um chefe de seita filosófica, a fim de que o destinatário, leitor, ouvinte, espectador, enquanto sujeito crítico, possa montar para si mesmo uma situação de julgamento, cujo juízo está menos na escolha do que na perspectiva crítica e dinâmica de encenar uma tal escolha.

Enquanto a morte de Peregrino também suscita um quadro de juízos referidos pelos personagens do drama, sendo que há uma referência direta à última cena do Fédon, após a morte de Sócrates, ${ }^{34}$ a cena de sua prisão, em consequência de sua atuação como líder religioso cristão, descreve, por um lado, o tratamento cuidadoso a ele dedicado pelos cristãos e, por outro, a pouca consideração a ele prestada pelo governador romano encarregado de julgá-lo, avaliando a sua conduta como pautada por uma insana busca de glória. Dessa forma, são apresentadas, em relação a Peregrino, duas possibilidades de juízo, a parcialidade do narrador tingindo de forma negativa a atitude judicativa dos cristãos, uma vez que, aceitando os fatos da fé de maneira irrefletida, não seriam eles capazes de avaliar acuradamente as situações e as pessoas, podendo ser enganados facilmente por um artista da representação, tal qual Peregrino, um góes, um farsante. ${ }^{35}$ É, por conseguinte, segundo um tal estado de espírito e através de um tal juízo que "o excelente Peregrino (...) era nomeado por eles como um novo Sócrates”. ${ }^{36}$

Através de um Peregrino-Sócrates e de um Demônax-Sócrates, podemos perceber um jogo de claro-escuro no tratamento luciânico dado à figura do filósofo imbricado em questões religiosas. Mesmo que se possa dizer que Demônax constitua uma idealização elaborada segundo os valores delineados por Luciano em sua obra (isso, certamente, está vinculado à liberdade do pensador e à sua autonomia de ação em relação a qualquer credo), o fato é que Demônax é descrito, no final de sua vida, como um homem santo, que suscita nas pessoas, além da admiração, a crença num certo poder da ordem do divino. ${ }^{37} \mathrm{Tal}$ como Peregrino, Demônax provoca a sua própria morte, mas não em busca de notoriedade pública; segundo Luciano, depois de ter vivido uma centena de anos, resolve, pela privação de alimentos, retirar-se da vida, uma vez que tinha compreendido que não podia mais bastar-se a si mesmo. Assim como os filósofos estavam presentes ao enterro de

\footnotetext{
${ }^{34}$ Luciano, Sobre o fim de Peregrino, 37; Platão, Fédon.

${ }^{35}$ Luciano, Sobre o fim de Peregrino, 13.

${ }^{36}$ Luciano, Sobre ofim de Peregrino, 12.

${ }^{37}$ Luciano, Demônax, 64.
} 
Demônax (tendo carregado o seu corpo até o sepulcro), assim também afluíram os cínicos para presenciarem a morte de seu herói, tratado por eles igualmente como homem santo.

A experimentação biográfica de Luciano (tendo assente que não consideramos o fenômeno biográfico na Antiguidade como o campo do historiador, nem de uma pretensa verdade histórica, embora tal modalidade faça uso de alguns procedimentos daquele e simule uma apropriação desta) ${ }^{38}$ apresenta-se como uma experimentação de espécies de filósofos, cuja atuação na vida é contemplada como um drama e avaliada positiva ou negativamente, de acordo com a harmonia ou a discrepância entre o que é enunciado ou mostrado e o que é vivenciado ou dramaticamente representado. Concordamos certamente com Brandão em que há uma tônica e uma constância no tratamento dado aos filósofos, que a crítica se faz menos ao filósofo em si do que àqueles que simulam uma aparência e os procedimentos referentes a determinada corrente (os filósofos pela metade, cuja conduta é marcada por mera exterioridade, sem um compromisso genuíno com os princípios éticos, espirituais e doutrinários); admitimos que nisso se descobre, de certa forma, a mesma intencionalidade dirigida a outros produtos culturais, como a história e a retórica, intencionalidade que ocasiona uma contraposição entre os discursos (caracterizados pelo compromisso com a verdade) dos filósofos, historiadores e oradores (e médicos) e a esfera de atuação dos poetas, dos pintores e dos sonhos, marcada pelo psêudos, pela "pura liberdade". 39 Concordamos, assim, que Luciano é um crítico da cultura e que sua crítica à religião (ou aos envolvidos em questões religiosas), de certo modo, possa se situar no nível geral da paidéia, concebida aquela, de forma semelhante, como produto cultural. No entanto, o fenômeno religioso parece gerar uma dificuldade para essa finalidade ou para a estratégia discursiva luciânica, pois, se há um próprio e um impróprio discurso, seja para o historiador, seja para o orador, seja para o filósofo, como se poderia definir um lógos, próprio ou impróprio, para a religião?

Quando se trata, não obstante, de questões religiosas, a estratégia luciânica é vinculá-las, de alguma forma, ao lógos filosófico (e, às vezes, ao lógos médico). ${ }^{40}$ O relato biográfico, como temos argumentado, é,

\footnotetext{
${ }^{38}$ Para o estatuto do historiador na obra luciânica, cf. Brandão, op. cit., 1992; para as várias concepções e apropriações do discurso histórico na Antiguidade, cf. Hartog, op. cit., 2001.

${ }^{39}$ Cf. Brandão, op. cit., 1992, p. 164-191.

${ }^{40}$ Cf. Brandão, op. cit., 1990.
} 
com efeito, o espaço discursivo eleito por Luciano (mas não o único) para abordar essa problemática a partir de um enquadramento pragmático da ação moral. O relato de um bíos fornece essa possibilidade de auferir um critério de verdade relativo à atuação prática do representante de uma dada doutrina ou crença; contemplar as ações deste numa narrativa biográfica propicia a possibilidade de um julgamento de valor conforme o seu engajamento legítimo ou fictício aos valores advogados. Por outro lado, todavia, se os prodígios forem considerados como os elementos distintivos de um relato de um bíos de caráter aretológico, então o próprio de tal discurso viria a ser, a partir da ótica luciânica, também da ordem do ficcional - o próprio desse tipo de discurso cujo exemplar mais evidente viria a ser a Vida de Apolônio de Tiana, de Filóstrato. ${ }^{41}$

O que se observa é que a tática de Luciano consiste em puxar a discussão para o terreno moral, cujo parâmetro seria aquele já indicado: a coerência entre vida e doutrina. Em vista disso é que podemos concluir que a escolha do gênero biográfico se torna, para Luciano, o meio por excelência de mostrar e pôr à prova figuras (com algum fundo histórico) cujas ações se inscrevem tanto no campo da filosofia quanto no da religião. As figuras-modelo desse tipo de perfil são Alexandre e Peregrino, mas mesmo Demônax pode aí ser incluído; isso é possível pelo seu envolvimento pessoal em questões religiosas, quer pela sua recusa em participar de qualquer culto, quer pela atitude dos atenienses, que o tratam como um homem santo no final de sua vida e promovem sua heroicização depois de sua morte. Não obstante, o seu perfil, nesse sentido, é pouco elaborado na narrativa, sendo enfatizada, mormente nas crias, a mesma opinião negativa e genérica em relação a magos e adivinhos $^{42}$ que Luciano expressa em outras obras. ${ }^{43}$

Como conclusão, diríamos que o bíos escrito por Luciano, por seu turno, enquadrar-se-ia num gênero biográfico cômico, também em relação de filiação com a história e com o gênero epidítico. Além disso, o biográfico se revelaria como um gênero misto ou híbrido por natureza; com efeito, se a história, por ter sempre na verdade o seu objetivo mais genuíno, não admite, segundo nosso autor, o elogio ou o artifício retórico da amplificação, o bíos, ao contrário, em sua vertente séria,

\footnotetext{
${ }^{41}$ Cf. van Uytfange, op. cit., p. 156-157; cf. também Elsner, op. cit., p. 22-37.

${ }^{42}$ Luciano, Demônax, 23, 25, 34, 37; cf. Branham, op. cit., p. 62.

${ }^{43}$ Cf. Jones, op. cit., p. 33-45; Caster, op. cit., 1937, p. 175-178.
} 
englobaria traços do encômio e, na vertente cômica, forjada por Luciano, faria uso do psógos, da censura, da injúria, da invectiva.

Se essa constituição do bíos, pela sua contaminação ou transposição do psógos (discurso de censura) a partir do gênero epidítico, já revelaria a base retórica em que Luciano opera, um exame de sua obra como um todo, a exemplo do que empreende Bompaire, certificar-se-ia do emprego ostensivo que ele faz dos gêneros retóricos e dos progymnásmata (exercícios retóricos preparatórios). ${ }^{44}$ Não obstante, cabe, por último, chamar a atenção para o modo específico de ele atuar no campo da retórica e que se vincula a uma forma de apelo à dramaticidade, como um constituinte estruturante de várias de suas obras, articulando gênero biográfico, narrativa histórica, enquadramento retórico e discurso sobre correntes filosóficas e sistemas de crença numa encruzilhada de narrativas e de sentidos.

\section{Referências}

ADRADOS, F. R. Historia de la fábula greco-latina. Madrid: Universidad Complutense, 1979.

ARISTÓTELES, Poética. Trad. Eudoro de Souza, ed. bilíngue. São Paulo: Ars Poetica, 1992.

ARISTÓTELES. Retórica. Edición del texto con aparato crítico, traducción, prólogo y notas por Antonio Tovar. Madrid: Instituto de Estudios Políticos, 1953.

BERGER, K. As formas literárias do Novo Testamento. Trad. Fredericus Antonius Stein, supervisão Johan Konings. São Paulo: Loyola, 1998.

BOMPAIRE, J. Lucien écrivain: imitation et création. Paris: E. de Boccard, 1958.

BRANDÃO, J. L. Narrativa e mimese no romance grego: o narrador, o narrado e a narração num gênero pós-antigo. Belo Horizonte: UFMG, 1996.

BRANDÃO, J. L.A poética do Hipocentauro: identidade e diferença na obra de Luciano de Samósata. Tese de doutorado. São Paulo: FFLCH-USP, 1992.

BRANHAM, R. B. Unruly eloquence, Lucian and the comedy of traditions. Cambridge/ London: Harvard University Press, 1989.

CASTER, M. Études sur Alexandre ou le faux prophète de Lucien. Paris: Belles Lettres, 1938. CASTER, M. Lucien et la pensée religieuse de son temps. Paris: Belles Lettres, 1937.

CLAY, D. Lucian of Samosata: four philosophical lives (Nigrinus, Demonax, Peregrinus, Alexander Pseudomantis). In: Aufstieg und Niedergang der Römischen Welt (ANRW). Teil II, Band 36. Berlin/ New York: W. de Gruyter, 1992, p. 3406-3450.

${ }^{44}$ Cf. Bompaire, op. cit., p. 239-469. 
DIÓGENES LAERTIOS. Vidas e doutrinas dos filósofos ilustres. Trad., introdução e notas de Mário da Gama Kury. Brasília: UNB, 1988.

ELSNER, J. Hagiographic geography: travel and allegory in the "Life of Apollonius of Tyana”. The Journal of Hellenic Studies, Cambridge, vol. CXVII, p. 22-27, 1997.

FILOSTRATO. Vidas de los Sofistas. In: Biógrafos Griegos. Trad. del griego y notas por Antonio Sanz Romanillos, José Ortiz y Sanz y José M. Riaño, prólogo general por Juan Martin Ruiz Werner, preámbulos parciales por F. de P. Samaranch y J. M. Riaño. Madrid: Aguilar, 1973.

HARTOG, F. O espelho de Heródoto: ensaio sobre a representação do outro. Trad. Jacyntho Lins Brandão. Belo Horizonte: UFMG, 1999.

HARTOG, F. A história de Homero a Santo Agostinho. Trad. Jacyntho Lins Brandão. Belo Horizonte: UFMG, 2001.

HÉRODOTE. Histoires. Texte établi e traduit par Ph.-E. Legrand. Paris: Les Belles Lettres, 1956 (livre I); 1948 (livre II).

HERÓDOTO. História. Trad. do grego, introd. e notas de Mário da Gama Kury. Brasília: UnB, 1998.

IPIRANGA JÚNIOR, P. O Hades Luciânico: espaço discursivo de inscrição da memória e do ficcional. Dissertação de mestrado inédita. Mariana: Instituto de Ciências Humanas e Sociais da Universidade Federal de Ouro Preto, 2000.

IPIRANGA JÚNIOR, P. Imagens do outro como um si mesmo: drama e narrativa nos relatos biográficos de Luciano de Samósata e na "Vita Antonii" de Atanásio. Tese de doutorado inédita. Belo Horizonte: Faculdade de Letras da UFMG, 2006.

JONES, C. P. Culture and society in Lucian. Cambridge/ Mass.; London: Harvard University Press, 1986.

LEME-LOPES, A. Como se deve escrever a história verdadeira: verdade, história e ficção segundo Luciano de Samósata. Dissertação de mestrado inédita. Brasília: UNB, 2002. LIMA, L. C. História. Fiç̧ão. Literatura. São Paulo: Companhia das Letras, 2006.

LUCIAN. Lucian with an English translation. Translation by A. M. Harmon. Cambridge/ Mass./ London: Harvard University Press, 1996 (vol. I); 1988 (vol. II); 1969 (vol. III); 1992 (vol. IV); 1996 (vol. V); 1990 (vol. VI).

LUCIANO. Obras. Trad. y notas por J. Alsina (vol. I) y J. L. N. González (vol. II). Madrid: Gredos, 1981 (vol. I); 1988 (vol. II).

LUCIANO. Obras. Vol. III. Trad. y notas por Juan Zaragoza Botella. Madrid: Editorial Gredos, 1990.

LUCIANO. Uma história verídica. Pref., trad. e notas de Custódio Magueijo. Lisboa: Inquérito, 1984.

MOMIGLIANO, A. De paganos, judios y cristianos. Trad. Stella Mastrangelo. México: Fondo de Cultura Económica, 1992.

MOMIGLIANO, A. La naissance de la biographie en Grèce ancienne. Traduit de l'anglais par Estelle Oudot. Strasbourg: Circé, 1991. 
MUSURILLO, H. Acts of the Christian martyrs (V, II). Oxford: Oxford University Press, 2000 (1972).

PAGUET, L. Les Cyniques grecs: fragments e témoignages. Ottawa: Les Presses de L'Université d'Ottawa, 1990.

REARDON, B. P. Courrants littéraires grecs de IIe. et IIIe. siècles après J.C. Paris: Les Belles Lettres, 1971.

REARDON, B. P. The form of Greek romance. Princeton/ New Jersey: Princeton University Press: 1991.

SAÏD, S. Le "je" de Lucien. In: BASLEZ, M.-F.; HOFFMANN, P.; PERNOT, L. (org.). L'autobiographie d'Hesiode à Saint Augustin: "Actes du deuxième colloque de l'équipe de recherche sur l'hellénisme post-classique". Paris: Presses de l'École Normale Superieure, 1993.

SCHWARTZ, J. (org.). Lucien de Samosate: "Philopseudès" et "De morte Peregrini". Paris: Les Belles Lettres, 1963.

SHAW, B. D. Judicial nightmares and Christian memory. Journal of early Christian studies, Ohio, vol. 11, n. 4, p. 533-563, 2003.

UYTFANGHE, M. van. L'hagiographie, un "genre" chrétien ou antique tardif? Analecta Bollandiana (revue critique d'hagiographie), Bruxelles, tome 111, p. 67-85, 1993.

WHITMARSH, T. J. G. Lucian. In: Narrators, narratees and narratives in ancient Greek literature (MNEMOSYNE). Supplementum 257. Leiden/ Boston: Brill, 2004, p. 465-476.

XENOFONTE. Ditos e feitos memoráveis de Sócrates. Trad. Líbero Rangel de Andrade. São Paulo: Abril Cultural, 1972 (“Os pensadores”, vol. II). 